\title{
Detours in Hungarian administrative criminal justice
}

\author{
Zsuzsanna ÁRVA Dr. PhD., habil.
}

\begin{abstract}
One of the key directions of change in the Hungarian administrative sanctioning system is represented by a shift from the classic, subjective sanctions that are difficult to be enforced by the authorities towards objective sanctions. This change has impacted the offenses established by the local governments specifically, which revived first in the form of decrees regulating anti-social behaviors, and subsequently that of peaceful public coexistence and the sanctions included therein. The process was also supervised by the Constitutional Court, however, the antecedents reach all the way back to the period preceding the change of regime in Hungary, when the legislator at first attempted to preserve the unity of offenses, which may be seen as a melting pot of numerous anti-administrative and petty crimes; then subsequently we could witness a degree of restoration despite all efforts in which the offenses have again assumed the characteristics of criminal law.

This paper provides an overview of the process that led not necessarily to the complete withdrawal of the Hungarian offense law but its termination in the classic sense of the term, while the elements of the legal institution continue to live on as other types of administrative sanctions and helped the institution of administrative criminal law survive.
\end{abstract}

\section{Keywords}

offenses, administrative criminal law, local governments, administrative sanctions, peaceful public coexistence

\section{Introduction}

The history of administrative criminal justice in Hungary goes back to misdemeanors, which used to be part of the trichotomy of criminal law and were considered crimes, while in the case of offenses the relationship with state administration, public administration became more emphatic. Therefore, the two areas could not be identified with each other automatically and legal scholarship did not find a common name for the area either until the 1970s when Gábor Máthé established the term of administrative criminal justice. The latter expresses problems related to questions of both substantive (misdemeanors or offenses) and procedural (court or public administrative jurisdiction) nature in this area. ${ }^{1}$

1 MÁTHÉ, Gábor: Von der Übertretung bis zur Ordnungswidrigkeit - Entwicklung der Rechtsinstituts in Ungarn, in: A közigazgatási büntetőbíráskodás fejlődése az utolsó 100 évben, MÁTHÉ, Gábor - RÉVÉSZ, Tamás (eds.), Budapest 1986, 84 . 
At the same time, administrative criminal law cannot be identified either with misdemeanors or the entirety of offenses because while the latter categories also appear in statutory law, this is mostly a theoretical construct. The terminology itself has been used in legal studies for more than one hundred years based on the work of James Goldschmidt, who argues that administrative criminal law is the entirety of those regulations on the basis of which the state administration imposes a penalty as an administrative consequence of infringing an administrative measure. ${ }^{2}$

The history of administrative criminal justice in Hungary and internationally has been characterized by constant changes as the relationship of this legal field with criminal law and administrative law has generated such a tension that kept it moving continuously. In this respect the Hungarian processes resembled the practice of other East-Central European countries going through a democratic transition, whereby misdemeanors were distinguished from other administrative sanctions. At the same time, Hungarian misdemeanor law (as noted at several points in this study) was for a long time based on the German regulation. The separate legal regulation of misdemeanors was first used in Germany in the field of economic law, when due to the economic trends of the postwar era such a quick and simple procedure had to be created that enabled decisions about a large number of cases within an adequate (administrative) framework. ${ }^{3}$ The conceptual separation of criminal law and misdemeanor law, which brought about a major breakthrough in the development of administrative criminal law, was also related to economic law. First, the act on economic crimes was established in 1949 based on the method of Schmidt Eberhard arguing for the quantitative separation of misdemeanors, then in 1952 the act on misdemeanors was created. As a result of decriminalization processes in transport law, however, the rules of procedure of the 1952 act had to be fundamentally revised so as to maintain the distinction between misdemeanors and crimes, thus the 1968 act that is still effective today was born (hereafter referred to as $\mathrm{OWiG}$ ). ${ }^{4}$

The need for change in Hungary was driven mostly by the requirements of the rule of law that have started such a multi-stage codification process the steps of which contribute to the better understanding of the concept and intersections of the legal field of offenses, and they necessarily lead to a rearrangement within administrative sanctions. The paper provides an overview of this process. When writing this paper I had the honor of getting access to those manuscripts by the Demokratikus Helyi Közigazgatás Fejlesztéséért Alapítvány [Foundation for the Development of Democratic Local Public Administration] that were collected by the major representative and expert of the field, Gábor Máthé, thus besides publicly available publications, I also had the opportunity to read a part of materials made in the Ministry of the Interior during the preparatory phase of codification.

2 GOLDSCHMIDT, James: Das Verwaltungsstrafrecht, Berlin 1902, 577.

3 GÖHLER, Erich: Gesetz über Ordnungswidrigkeiten, München 1992, 2.

4 KATHOLNIGG, Oskar: A kisebb súlyú bűncselekmények Németországban. A szabálysértésekről szóló törvény, in: Magyar Jog, 43, 1996, 8, 485-486. 


\section{The era of the change of regime}

Hungary codified offenses for the first time with Act I of 1968. The theories justifying the inclusion of the law on offenses within administrative law only apparently covered the paradox of administrative criminal law but did not put an end to the question of searching for criteria of distinction; they only pushed it from differentiation within criminal law to the border of administrative law and criminal law. Deregulation and the need for regulations as a result of the change of regime called attention to numerous contradictions and hiatuses. The re-regulation of the field was considered to be inevitable in the 1980s already, thus in 1986 the first codification committee was established which first operated within the Ministry of Justice and as of 1990 in the Ministry of the Interior. ${ }^{5}$ Codification took yet another turn in 1990 as due to Government resolution no. 2019/1990. (HT.11.), which commissioned the Ministry of Justice to survey the Hungarian legal system and for the purposes of harmony examine the consequences expressed by the case law of the European Commission on Human Rights, as a result of which, the codification of the legal field of offenses continued in the Ministry of the Interior.

In terms of professional preparation, in which numerous theoreticians and practicing experts participated, the following main issues could be outlined:

- the relationship of the offense law and criminal law, the concepts of diversion and back-channeling;

- the relationship of offense law and international guarantee requirements, with special regard to the Convention for the Protection of Human Rights and Fundamental Freedoms (hereafter as: Convention);

- in connection with the offense forum system, the clerk 6 as an acting authority and the offense statutory rights of local governments.

\section{Diversion and back-channeling theories}

The theories of diversion and back-channeling practically try to answer the question related to the positioning of offenses (formerly misdemeanors) within the legal system and closely linked to this to that of the forum system. The roots of the dilemma reach all the way back to the public administration reform of 1901. It occurred at this time already in terms of codification that in all cases of administrative competence (then misdemeanors) a judicial forum should act at least in the appeal phase but the problem was at that time also that due to the high number of misdemeanors this would have meant too much of a burden for the courts.

At the time of the repeated codification of the law on offenses, the collision of the two theories came into the focus again. ${ }^{7}$ While representatives of the idea of back-channeling

5 MÁTHÉ, Gábor: Közigazgatási büntetőjog vagy "Janus-arcú" büntetőjog?, in: Magyar Közigazgatás, 51, 2001, $6,323$.

6 The clerk is chief executive in the Hungarian local self-government system, and s/he heads the office of the body of representatives.

7 MÁTHÉ, Gábor - PAPP, László: Javaslat A magyar szabálysértési jog továbbfejlesztésére, figyelemmel az Európai Emberi Jogi Egyezmény szövegére és az Emberi Jogok Európai Bíróságának joggyakorlatára, Ministry of the Interior: Budapest 1991, (Manuscript). 
argued for the separation of the law on offenses and the returning of certain acts into criminal law, the followers of the theory of diversion argued for the maintenance of a separate law on offenses. The essence and feasibility of the particular theories, however, is to be found in the impact of the concepts on the forum system specifically, as according to back-channeling all of the petty offenses should be decided by a court, while according to diversion it is enough if a court participates in the appeals procedure. Diversion also argues that there is a relatively high number of cases with floating borders among offenses due to which the separation of criminal and anti-administrative actions is impossible and any demarcation carries in itself the possibility of necessary restoration.

When discussing the relationship between the law on offenses and criminal law, we also need to mention the reflections on the former qualitative ${ }^{8}$ and quantitative ${ }^{9}$ theories that was carried out mostly by Gábor Máthé who showed that the dual nature of the legal institution had been present ever since its establishment. Máthé studied the former theories also from the perspective of the approaching codification, as a result of which, he argued for the unity of the legal field. ${ }^{10}$

\section{The question of international guarantees}

The consideration of international guarantees and the practice of international courts was a decisive factor in codification, which indirectly also affected the development of the Constitutional Court's case law. ${ }^{11}$ The feasibility of the requirements specified in the Convention for the Protection of Human Rights and Fundamental Freedoms was preceded by careful deliberation as the Ministry of the Interior indicated it in 1990 already that the feasibility of the principle of fair trial stipulated by Article 6, Section 1 represents a problem in connection with the law on offenses, as it prescribes judgement by an independent, impartial court in connection with criminal law cases and this in the case of offenses means that the right to turn to a court is made general. Despite the fact that the government had already started the preparations for the repeated codification of the area of offenses, it could be anticipated that the new law would not be promulgated before the announcement of the Convention.

The preliminary studies concentrated on the outcomes of the similar cases of the court so far, with special emphasis on the Öztürk and Belilos cases. In connection with the case of Abdulbaki Öztürk ${ }^{12}$, the court, after the examination of the entire system of the German regulation, established that no clear line can be drawn between criminal law and the law on offenses as certain endeavors for decriminalization are always present in criminal law. Therefore, which branch of law a specific state categorizes a certain action in cannot be a determining factor in itself, it can only be one of the elements of the governing criteria.

8 ANGYAL, Pál: A közigazgatás-ellenesség büntetöjogi értékelése, Budapest 1931.

9 MOLNÁR, Miklós: Adalékok a közigazgatási jogi szankció hazai elmélettörténetéhez, Budapest 1990.

10 MÁTHÉ, Gábor: Megoldhatatlan-e a szabálysértési felelősség, in: Belügyi Szemle, 1989, 2, 3-9.

11 VITKAUSKAS, Dovydas - DIKOV, Grigoriy: Protecting the right to a fair trial under the European Convention on Human Rights, Strasbourg 2012.

12 Case of Öztürk v. Germany, online: http://hudoc.echr.coe.int/eng?i=001-62111 (Downloaded 9 October 2019). 
Besides the classification within branches of law, the nature of the act and the sanction shall also be studied, which in most cases includes the deprivation of liberty or financial penalties (fines). If in the latter case the preventive or repressive nature can be identified, the stipulations of the Convention shall be used even in the case of a minor infringement of the law. At the same time, the Court does not perceive the decriminalization processes to be contrary to the Convention if the state provides the appropriate legal guarantees. ${ }^{13}$ The Belilos case ${ }^{14}$ affected Swiss law in connection with which the court ${ }^{15}$, on the one hand, confirmed its opinion expressed in a former case (Albert and Le Compte), according to which the review shall cover both questions of fact and law, and on the other hand, it concluded that the interpretative statement does not exclude the jurisdiction of the court in its case.

Based on the two cases above, the preparatory study conducted by the Legal Department of the Ministry of the Interior concluded that the system of offenses has to be transformed in a way that judicial review shall be guaranteed and it shall apply both to the review of facts and legal issues. ${ }^{16}$ To ensure an approach involving different points of view, several scholars were involved. ${ }^{17}$ At the meeting of the Club of Criminal Lawyers on 28 February 1992, Márta Bittó explored the question of compatibility between the law on offenses and the Convention. Based on the transcript of the lecture, she argued that a reservation was necessary, however, she also expressed her concerns in the sense whether the Court could invalidate it in a particular case. ${ }^{18}$ The written memo of the meeting, however, included an extended version of the conference presentation which already included an international comparative survey with regard to the reservations concerning the Convention, based on which Bittó outlined risks in connection with the possible annulment of the reservation, also emphasizing that it was not certain at all that such a case would reach the court. ${ }^{19}$

In the end, Hungary added a reservation to Article 6, Section 1 of the Convention stipulating the principle of a fair trial with reference to the law on offenses. Later, in a scholarly publication Bittó argued that no reservation with such a content could have been added to the Convention; ${ }^{20}$ on behalf of the Ministry of the Interior Krisztina Berta reflected on the article, explaining that the opinion expressed in the article was unfounded

13 TAUBNER, Zoltán: Manuscript, Ministry of the Interior: Budapest, May 1991. See also MOLE, Nuala - HARBY, Catharina: The right to a fair trial. A guide to the implementation of Article 6 of the European Convention on Human Rights, Strasbourg 2001, 2006, 68-69 and VITKAUSKAS - DIKOV, 17.

14 Case of Belilos v. Switzerland, online: http://hudoc.echr.coe.int/eng?i=001-57434 (Downloaded 9 October 2019).

15 See also MOLE - HARBY, 31.

16 BÁN, Tamás: Manuscript, Ministry of the Interior: Budapest, 6 May 1991.

17 PAPP, László: A szabálysértési jog kialakulása és fejlődése, a hatályos szabálysértési jog jellemzői, a kodifikáció tendenciái hazánkban, Ministry of the Interior: Budapest 1992, (Manuscript), 1-16.

18 BITTÓ, Márta: Szabálysértési Eljárás kontra Emberi Jogi Egyezmény. Keynote speech at the meeting of the Club of Criminal Lawyers on 28 February 1992 titled "Opportunities of administrative criminal justice under the rule of law", Budapest 1992, (Manuscript), 1-12.

19 Memo of the lectures delivered at the meeting of the Club of Criminal Lawyers on 28 February 1992, Club of Criminal Lawyers: Budapest, 16 March 1992, (Manuscript).

20 BITTÓ, Márta: A bírósági eljáráshoz való jog és a magyar szabálysértési fenntartás, in: Magyar Közigazgatás, 43, 1993, 5, 270-277. 
or was not based on appropriate foundations. ${ }^{21}$ At the same time, based on the rather extensive jurisprudence of Article 6, it could be anticipated that such a regulation would be in harmony with the stipulations of the Convention in which judicial review is guaranteed in questions of fact and law alike.

\section{Offense authorities, activities of local governments}

During the preparatory stage, a discussion paper written in 1997 in the Ministry of the Interior examined the work of the "local government" offense authorities specifically. The document also started out from the traditional postulate that offenses are two-faced acts, thus one part of them are anti-administration, while another part belong under petty criminal law. However, the procedures by local government-like bodies have centuries-long traditions as based on the 1879 Act on Misdemeanors and the implementing regulations ${ }^{22}$ several such public administrative bodies acted both at the first and second degree. The acting of local public administrative bodies as authorities for offenses did not end during the council system either although at that time the state administrative bodies made decisions about offenses; then after 1990 the competence law settled the fundamental questions that considered the clerks of small towns, cities, cities of county rights, and the capital district to be the authorities responsible for offenses in general. It occurred at that time already that the solution was not well founded theoretically as even though the clerk was not an administrative body, it had a dual role; but typically such cases of a public administrative nature should be given to it in terms of sanctions that involve a degree of interest by the local government. The latter one is usually absent in the case of offenses, thus the discussion paper proposed that the clerk should not be a general offense authority but at most it shall be able to act only in the case of offenses related to the local government as in the position of a general authority it has to deal with the most diverse cases. $^{23}$

The discussion paper examined the procedure of clerks as authorities responsible for offenses based on statistical data as well between 1990 and 1996. In this process, it was established that with the exception of 1994 the number of accusations showed a slight increase every year (2-5\%), however, within this the number of accusations due to offenses stipulated by local government decrees increased continuously and to an ever growing extent. Similarly, the amount of fines imposed increased to a significant extent (at first by $13 \%$, then in the subsequent period by as much as $46 \%$ compared to the preceding year). Based on data concerning termination, they also concluded that successful investigation exhibited an improving tendency in consideration of the fact that an increasingly smaller proportion of cases started based on the accusations were terminated. ${ }^{24}$

21 BERTA, Krisztina - MÉSZÁROS, József: A szabálysértési jog átfogó felülvizsgálatáról, in: Magyar Közigazgatás, $43,1993,5,278-289$.

22 38.547/1880. BM. and the subsequent 65.000/1909. BM.

23 BEKÉNYI, József - KINCSES, Ildikó - MÁTHÉ, Gábor - PAPP, László: Az önkormányzati szabálysértési hatóságok tevékenysége, a szabálysértési tényállásokat megállapító rendeletek. Discussion paper. Ministry of the Interior: Budapest, November 1997, (Manuscript).

24 Ibidem, 11-19. 
The studies specifically touched upon the regulatory practice of local governments regarding offenses, also discussing its theoretical foundations. In this regard the starting point was that local governments can enact decrees based on statutory authorization and for the settlement of local social conditions. Although not clearly, the discussion paper included the decrees on offenses within the first category, as based on the definitions of the act on offenses the local government may establish an offense, thus the authorization in this regard may be considered to be of a general nature.

The typical topics before the effective date of Act II of 2012 were the following:

- water supply and the local regulation of water supply;

- regulations concerning the settlement's coat of arms, flag, and other symbols;

- maintenance and use of cemeteries;

- keeping animals, with special regard to dogs;

- use of public areas;

- order of markets and fairs;

- use of public services, with special regard to the chimney sweeping services;

- public sanitation.

It may be established based on the above that the offenses regulated by the local governments already covered a relatively broad set of local issues and, in particular cases regulated the order of peaceful public coexistence, from which the paper highlighted and introduced several offenses with a representative purpose. These also included some cases that were still regulated by council decrees, however, the given local government did not want to repeal them in consideration of the fact that they would not have had the competence by that time to regulate the legal relationship serving as its basis. Among the local government cases there are several that the authors considered to be dormant, indicating that based on these no sanctioning or procedure had been initiated for a long time, thus they proposed their repeal (along with the council decrees in general). The differing legislative quality of local government decrees was also typical, as some used multiple sanctions and at the same time did not differentiate the maximum amount of the fine between the different actions. Due to all of these anomalies, this proposal already pushed for the limitation of local government offenses, possibly by establishing specific scopes of cases, and at the same time, it also suggested for consideration that instead of offenses another legal institution (e.g., administrative fines) should be introduced that could be used to react to the local circumstances and whereby the fine would be credited to the imposing authority.

This latter issue, however, was implemented based on the 2012 Act on Offenses and the new local government regulation in two steps, also due to the decision of the Constitutional Court. Thus first it were Article 51, Section (4) and Article 143, Section (4), Point e) of Act CLXXXIX of 2011 on Local Governments of Hungary (hereafter as the Act on Local Governments) that authorized local governments to regulate and sanction anti-social behavior, then Constitutional Court decision no. 38/2012 (XI. 14.) annulled the mentioned authorization, and subsequently based on Article 143, Clause (4), point d) of the Act on Local Governments, the local governments specify the basic rules of peaceful public coexistence as well as the legal consequences of any failure to comply with these, as administrative sanctions. 


\section{The results of codification between 1997 and 2012}

\section{Before 1999}

In 1996, the Ministry of the Interior and the Ministry of Justice made a joint proposal for the Government on the concept for the regulation of the law on offenses. The preparatory material also introduced the standpoint related to the independence of offense law, the possible scope of regulatory stipulations with which regulation on the legislative level is possible together with the preservation of the competence of public administrative bodies. In this sense the concept considered the legislative power of the government to be problematic, while it argued that the power of local governments to regulate local public order and behaviors posing a threat to the order of administration should be preserved due to the tasks of the local government. ${ }^{25}$ As a result of preparation, the Government accepted Government resolution no. 1078/1996 (VII. 19.) on the concept of the regulation of the offense law, which listed the most important elements of the regulation in 12 points. In terms of the development of the offense law in Hungary and the creation of the new code, Constitutional Court decision no. 63/1997. (XII. 12.) also had a major impact as it made the ratification of the law including the new guarantees a must. In its decision the Constitutional Court established that the Parliament did not perform the re-regulation of the field of offenses in line with the stipulations of the Constitution, and at the same time it annulled several sections of the former code, deducing the need for judicial review based on two different stipulations of the Constitution, separately for cases of a criminal and administrative nature.

Some justices added dissenting and parallel opinions to the resolution. One of the most often quoted of these is László Sólyom's parallel opinion, also joined by János Németh and Tamás Lábady. The opinion contested the applicability of Article 50, Section (2) of the Constitution in the case of offenses and called attention that in the case law of the Supreme Court the resolutions on offenses do not qualify as administrative resolutions either as they do not judge cases of an administrative nature. The separation is problematic and difficult to implement according to the already introduced professional opinions as well, what is more, it is not relevant in terms of the need for judicial review either; moreover, the opinion also mentions that cases involving offenses shall be taken to administrative or criminal courts within the scope of review.

A significant part of former scholarly publications shared the above ideas as opposed to the majority opinion of the decision. Gábor Máthé considered the mixture of the organizational and procedural approaches to be self-contradictory, while the constitutional rationale to be an example of formal logic, with the dogmatic foundations missing. ${ }^{26}$ Péter Kántás also criticized the artificial separation, while Marianna Nagy did not agree with the opinion of the Constitutional Court either, arguing that the requirement for judicial review could be deduced exclusively form Article 50, Section (2) of the Constitution also, in consideration of the fact that the opinion of the Supreme Court in connection with offenses is not consistent from a theoretical point of view. ${ }^{27}$

25 Proposal, 6-92/1996, Ministry of the Interior - Ministry of Justice: Budapest 1996, (Manuscript).

26 MÁTHÉ, Közigazgatási..., 325.

27 NAGY, Marianna: A közigazgatási jogi szankciórendszer, Budapest 2000, 80-86. 


\section{The code of 1999 and seeking the way}

The ratification of the 1999 code was surrounded by great expectations already due to the aforementioned, but it could not meet such expectations despite the long preparatory phase. Similarly to the former stipulations, the law maintained the unity of substantive and procedural law as a result of which it received a lot of criticism and the idea of amending it occurred practically right after enactment. ${ }^{28}$ The categorization of offenses within the legal branches was not clear based on the new code either, as the regulation continued to maintain the duality of the field as also confirmed by the Constitutional Court. In connection with the scholarly debate related to the law ${ }^{29}$, the advantages and disadvantages of diversion and back-channeling were revisited but the determination of the bases of responsibility was also among the debated conceptual questions. ${ }^{30}$

Similarly to the earlier ones, the 1999 law included a formal definition of offenses instead of a substantive one and it regulated the scope of norms regarding offenses in line with the historical legal traditions in Hungary. The latter was also criticized by legal publications. Péter Kántás disputed the broad competence of the government in establishing offenses, however, the competence of local governments also carried in itself certain problematic elements. There was also debate about the order of the types of punishments, actual confinement, expulsion, and the practical utilization of work of public interest. ${ }^{31}$

Soon afterwards, Parliament resolution no. 71/2004. (VI. 22.) also stated the objective of reviewing the law, along with its re-creation. Although formerly a draft was written in the Ministry of the Interior, no novel amendments were made, nor was a new law accepted. They claimed that the reason for this included circumstances that "could not be anticipated" in advance and the transformation of the system of legal consequences to be applied, the main objective of which at the time was to eliminate confinement as a punishment. ${ }^{32}$

Among the problems to be solved, one could find the unification of the fragmented authority system that called for the making of a new law; a good opportunity for this was presented by the reform of the criminal law and the new codification. Due to the social and economic changes, however, such new circumstances have also occurred that required a significant reform of the offense law and the establishment of new legal institutions. This includes the requirements articulated with regard to traffic patrol that were aimed at the reduction of traffic accidents. This included the draft aimed at the objective liability of the vehicle's operator that was finally added to Act I of 1988 on the Administrative Rules of Road Transport by Act CLXXV of 2007. Although the law stipulated this way does not belong to the terrain of offense law anymore, the connection is still obvious: the legislator reclassified the so far subjective sanction into an objective one with reference to prevention and improving success.

28 HAJDÚ, Mária: A szabálysértési jogalkalmazás gondjai, in: Magyar Jog, 51, 2002, 4, 241.

29 KÁNTÁS, Péter: Mérlegen az új szabálysértési törvény, in: Belügyi Szemle, 47, 1999, 10, 18-19 and ZÁMBÓ, Géza: Jogalkalmazói nézőpontú észrevételek a szabálysértésekről szóló 1999. évi LXIX. törvény módosítására vonatkozó tervezethez, in: Magyar Közigazgatás, 52, 2002, 4, 220-229.

30 SPITZ, József - SZABÓ, Sándor: Jogalkalmazói pillanatfelvétel az új szabálysértési törvényről, in: Magyar Jog, 48, 2001, 1, 7-23.

31 KÁNTÁS, Mérlegen..., 18-26.

32 Report: Report no. J/15234. of the Republic of Hungary, Budapest, 29 March 2005, 30. 
As the Constitutional Court in its decision 63/1997. (XII. 12.) argued for liability based on guiltiness in the case of offenses, the presumption of guiltiness was not possible within the system of offenses. Constitutional Court decision no. 498/D/2000. partly answered the question whether reclassification within objective sanctions was a constitutional solution in line with the rule of law, showing that the legislator had broad discretion in the process of regulating the conditions and extent of using the sanction.

It was Constitutional Court decision 60/2009. (V. 28.) that decided expressis verbis on the necessity of the specific preventative objective in the field of transportation, as it considered those objective sanctions based on legal regulations to be constitutional also that were known in the legal system before as sanctions with a subjective basis. The Constitutional Court confirmed that objective liability in itself was not unconstitutional and it was not in conflict with the principle of the rule of law. For the purposes of enforcement, the state may use sanctions among which objective sanctions encourage and facilitate legal certainty. The legislator has discretion to decide what kind of a liability scheme it establishes within the framework of the given branch of law, thus it also has the option to create new legal fields besides the already existing branches, reflecting on new social phenomena this way also. The objective sanctions that are independent of guiltiness, however, need to meet the following criteria: the sanction or the norm including the presumption of liability shall be clear and have a fair content and it should be possible to challenge the presumptions used.

\section{New paths of Act I of 2012}

Act II of 2012 that was created as a result of preparation has brought about clear changes in the field of administrative criminal justice as it clearly pushed the legal field in the direction of criminal law, while it also reduced the number of offenses by terminating the right of local governments and other public administrative bodies to regulate offense sanctions and prescribing that offenses may only be established by law.

The shift towards criminal law, however, can also be seen in other areas. Thus, for example, instead of a reference to anti-administration among the regulatory objectives of the Preamble, the practical objectives of the administrative sanction appear that are broader than the theoretical objective ${ }^{33}$ and the text is also much more reminiscent of the codification approach established by Act XI of $1879^{34}$ that emphasized the preventive nature and smaller weight of misdemeanors compared to crimes, also acknowledging the aims for decriminalization.

The move away from administrative law is also reflected by the novel, substantive definition that has two key starting points: possibility for punishment based on law and threat to society. The former is a novelty in the law on offenses as during the close to 200-year-long history of the legal area it had never happened that the legislator would have prescribed determination by law exclusively and thus enforce the principle of nullum crimen sine lege also in the case of administrative criminal justice. As a result, one of the founding stones for the classic interpretation of administrative criminal law is not enforced, namely

33 MADARÁSZ, Tibor: Az államigazgatási jogi szankció fogalma és fajtái, Budapest 1989, $37-42$.

34 SZATMÁRI, László: Bírság a magyar államigazgatásban, Budapest 1990, 81-84. 
determination by public administration. The inclusion of the threat to society as part of the definition represents a direct and closer relationship with criminal law, as theoretically it could even bring up the question of quantitative demarcation.

The stricter sanctioning system also indicates a closer link to criminal law that is not expressed only in terms of degree but also in the introduction of new types of punishment and the changes in the conditions of utilization. The legislator strengthened the role of confinement while they do not attempt the collection of unpaid fines anymore. The attributes as an independent legal institution are further strengthened by the fact that the ne bis in idem principle is enforced by the new code not only in terms of crimes but also other administrative sanctions. The existence of independent substantive and procedural rules also have a similar effect, while last but not least a new quantitative decriminalization also occurred that reduced the number of crimes against property by close to a quarter. The Constitutional Court in its decision 38/2012. (XI. 14.) claimed about the process that offenses lost their role in sanctioning anti-administrative behavior and its "petty criminal law" nature became dominant. Thus the restoration of the trichotomous criminal law system came within reach that was considered to be difficult to implement previously.

The amendment of the effective law on offenses with Act XLIV of 2018 recently shook yet another pillar of the legal field that may now be termed "administrative" criminal justice in quotation marks only as it also terminated the exclusively alternative nature of confinement as a punishment.

\section{Local government legislation: peaceful public coexistence, the vision of administrative criminal justice}

Parallel and also in response to the new law on offenses, such rules have been added to Act CLXXXIX of 2011 on Local Governments that made the enactment of rules on antisocial behavior possible for the representative body of the local government. This, however, was annulled rather quickly by the Constitutional Court in its decision no. 38/2012. (XI. 14.), qualifying the authorization to be of a bianco and unbounded nature. According to the explanation of the decision, establishing such a punishment, sanction as a legal consequence of an unlawful conduct that provides an opportunity for exercising coercive measures by the state, shall not be considered part of local public affairs. Such rules can be adopted by local governments only if authorized by law and within its scope, and it is in line with the requirements of the rule of law only with substantive legal guarantees prescribed by law.

Until annulment, the local governments adopted several hundred regulations, which concerned mostly such issues of neuralgic importance from the point of view of constitutional law as scavenging and begging and only one-eighth of the regulations included any other affairs. Based on the decision of the Constitutional Court, the local governments had to annul these decrees, which was also supervised by the State Territorial Representative, also expressing that they consider the establishment of original norms regulating and sanctioning local community life based on the fundamental law to be undesirable. 
At the same time, Article 32, Section (2) of the Fundamental Law of Hungary ${ }^{35}$ specifically stipulates that the local governments, acting within their functions, can regulate such social relations independently that are not regulated by any other law, thus the sanctioning regulations can be in harmony with the Fundamental Law. The basic responsibilities and functions of local governments are partly governed by the Fundamental Law and partly by the Act on Local Governments, and based on Article 4 of this act the stipulation of these laws may fall within the scope of defining the conditions of cooperation with the population in connection with the notion of local public affairs. In Article 143, Section (4), point d) of the Act on Local Governments, the legislator expressly authorized the local governments to specify the basic rules of peaceful public coexistence as well as the legal consequences of any failure to comply with them.

The practice of regulating and sanctioning peaceful public coexistence was spreading among local governments and the regional government offices tried to act against it and even the Commissioner for Fundamental Rights conducted an investigation. ${ }^{36}$

Finally, the Constitutional Court had to answer the question related to the harmony of this practice with the Fundamental Law. Constitutional Court decision no. 29/2015. (X. 2.) confirms that the basic rules of peaceful public coexistence are composed of both written and unwritten rules, among which there is space for sanctioning regulations enacted by the representative body also, in line with the first limb of Article 32, Section (2) of the Fundamental Law. Such a type of regulation, according to this body, does not violate the principle of subordination to the act on public administration or that of legal certainty or separation of powers due to the framework type of authorization. As a general rule, it is also the Curia that has authority to review these decrees, also maintaining the competence of the Constitutional Court in cases violating the Fundamental Law. Thus it can also be reviewed whether the regulations are in harmony with the Fundamental Law or not, whether the constitutional values and principles specified in Article I of the Fundamental Law were infringed, if the regulation meets the requirement of necessity and proportionality, and also whether the local circumstances substantiate the regulation of prohibited behavior and their legal consequences.

Later, besides the initial theoretical and practical problems, the conformity of the establishment of the new legal field with the Fundamental Law was confirmed by the Constitutional Court several times. In its decision no. 3/2016. (II. 22.) the Constitutional Court stated again that it could not be presumed ab ovo that the local governments would practice the broad regulation enacting opportunity granted to them by law in an abusive manner. Although the Curia did not exclude the option that a regulation would have such an outcome, it also stated that these cases could be averted by the courts and the Constitutional Court.

Constitutional Court resolution no. 7/2017. (IV. 18.) did not even doubt the legal basis of the decrees regulating peaceful public coexistence but explored another aspect starting out from the fact that a local government decree may be adopted for the provision of a task or service on the scale of a local government within the scope of local public affairs that may even affect fundamental rights, if it is in compliance with the limitation included

35 Constitution of Hungary has been called the Fundamental Law (of Hungary) since 2012.

36 Commissioner for Fundamental Rights, 1992. 
in Article I, Section (3) of the Fundamental Law. The parallel opinions provided a more nuanced approach in this regard also, confirming that local governments may adapt rules affecting fundamental rights on the level of regulations as only the most important rules belong to the field of legislation.

\section{Conclusion}

Based on the above, while the offense law established by Act 16 of 1953 maintained its clearly administrative nature until 2012, and based on Act II of 2012 it continuously shifted towards criminal law, the administrative criminal law of local governments was revived. Due to the above-mentioned regulatory elements of the currently effective code, with special regard to offenses that may be regulated only by act, the classic administrative criminal law in the Goldschmidtian sense cannot be found anymore among the effective offenses. The shift towards criminal law and the break with administrative-like foundations was further strengthened by the changes in 2018, which stipulate the punishment of habitual residence in public areas (widely known as homelessness) only with confinement under the conditions stipulated by law.

Parallel with this process, the administrative sanctions of local governments have appeared as new elements. The summarizing paper written in the Ministry of the Interior in 1997 also foreshadowed the solution that the offenses regulated by local governments should be replaced by another legal institution, whereby the local government could react to local infringements of law by regulating local relations and in which the fine would be credited to the imposing authority. The first attempt in this regard involved the authorization for the regulation of antisocial behavior, after the termination of which the opportunity opened for the regulation of peaceful public coexistence where fines are imposed on those who infringe the local rules. In this regard, by means of the regulation and sanctioning of peaceful public coexistence, a new type of administrative sanction has been created and the legislator has so far only reflected on it by touching upon certain elements. Thus at the beginning, by fitting the substantive rules among the public administration procedural rules, the legislator specified the types and degree of sanctions that may be used in the law that brought the offense law into effect (modifying the rules of the administrative procedures). The rationale of the act unambiguously states that the legislator created the option for administrative fines instead of the removed offenses. Ultimately, the new area gained recognition with Constitutional Court decision no. 29/2015. (X.2.). Currently, Act CLXXIX of 2017 on the Temporary Rules for Sanctioning Administrative Offenses and Amending Certain Laws in Connection with the Reform of Administrative Procedural Law and Repealing Certain Stipulations of Law stipulates the upper limit of the administrative fine that may be established based on the decree of the local government's representative body, which in the case of natural persons amounts to HUF 200,000, and in the case legal entities and organizations without a legal personality amounts to 2 million Forints. Moreover, it also stipulates ${ }^{37}$ the use of the principle of proportionality, this way reflecting on the former differentiability, according to which the local governments usually threaten every violation of law with the maximum sanction.

37 Article 3, Section (2) of Act CLXXIX of 2017. 
Although the offense law has not ceased to exit yet, it has lost its original attributes due to the termination of administrative legislation, which was further strengthened by the non-alternative option of confinement used in connection with habitual residence in public areas; thus the legal area, even if not on the level of laws but that of theory, is shifting more and more towards the implementation of criminal law trichotomy.

As opposed to this, the sanctions adopted by the local governments represent a continuously transforming and extending area. The decrees enacted by the local governments in Hungary can still be found in the section of the National Legislation Database (Nemzeti Jogszabálytár) including local government decrees under a separate heading. I have already introduced the practice of the Curia and the Constitutional Court related to these in my paper titled the "Local Governments and the Concept of Good Governance", 38 thus in this article I focus mostly on theoretical considerations.

In setting the paths, the regional government offices also got an important role besides the local governments and they perform the control of the enactment of regulations within the scope of legal supervision practiced by the Government and based on their initiatives the Curia and the Constitutional Court may also act; however, in this area the activities of the Commissioner of Fundamental Rights also play a major role. The theoretical foundations are still absent to a great extent in this regard, but it is already certain that the essence of the legal institution, the right of the local governments to enact administrative sanctions was preserved for the future. The point of this right is exactly the wide scope and authorization itself as the essential basics were established by the legislator first with the above-mentioned regulation of the administrative procedure. It can also be concluded from these substantive rules that the procedure has to be conducted in line with the rules of general administrative proceedings, just as the type and degree of the sanction is also clarified, similarly to the fact that a natural person and a legal entity may both be involved in the procedure. It derives from the rules of the Act on Local Governments that the regulatory local government decree may authorize a local government body, typically the clerk, to utilize the sanction.

In terms of which social relationship it includes within its regulatory scope and which of these it sanctions, however, the local government can decide within a broad framework. It also derives from the foundations stated above that the sanction is of a material but objective nature, and the prosecution of legal entities cannot be excluded either.

The designation of the fundamental right framework is among the issues to be clarified, also in consideration of the fact that the regulation of local governments may also affect certain fundamental right issues. In this regard it will ultimately be the task of the Constitutional Court to specify the borderlines from case to case. Conflicts with other laws may represent an additional point of dispute, which, however, may potentially emerge in the case of all local government decrees; however, because of this it really cannot be presumed ab ovo that the decrees would be unlawful. The examination of this at the preparatory stage is the task of the clerk, while in the case of adopted regulations that of the regional government offices, while based on their initiative the Curia acts in disputed matters. In order to avoid any infringement of fundamental rights, however, even a case law catalogue could be compiled or best practices could be shared in this topic with the involvement of the clerk.

38 ÁRVA, Zsuzsanna: Local governments and the Concept of Good Governance, in: Curentul Juridic, 78, 2019, $3,53-65$. 


\section{References}

ANGYAL, Pál: A közigazgatás-ellenesség büntetöjogi értékelése, Budapest 1931.

ÁRVA, Zsuzsanna: Local governments and the Concept of Good Governance, in: Curentul Juridic, 78, 2019, 3, 53-65.

BÁN, Tamás: Manuscript, Ministry of the Interior: Budapest, 6 May 1991.

BEKÉNYI, József - KINCSES, Ildikó - MÁTHÉ, Gábor - PAPP, László: Az önkormányzati szabálysértési hatóságok tevékenysége, a szabálysértési tényállásokat megállapító rendeletek. Discussion paper. Ministry of the Interior: Budapest, November 1997, (Manuscript).

BERTA, Krisztina - MÉSZÁROS, József: A szabálysértési jog átfogó felülvizsgálatáról, in: Magyar Közigazgatás, 43, 1993, 5, 278-289.

BITTÓ, Márta: Szabálysértési Eljárás kontra Emberi Jogi Egyezmény. Keynote speech at the meeting of the Club of Criminal Lawyers on 28 February 1992 titled "Opportunities of administrative criminal justice under the rule of law", Budapest 1992, (Manuscript).

BITTÓ, Márta: A bírósági eljáráshoz való jog és a magyar szabálysértési fenntartás, in: Magyar Közigazgatás, 43, 1993, 5, 270-277.

Case of Belilos v. Switzerland, online: http://hudoc.echr.coe.int/eng?i=001-57434 (Downloaded 9 October 2019).

Case of Öztürk v. Germany, online: http://hudoc.echr.coe.int/eng?i=001-62111 (Downloaded 9 October 2019).

GOLDSCHMIDT, James: Das Verwaltungsstrafrecht, Berlin 1902.

GÖHLER, Erich: Gesetz über Ordnungswidrigkeiten, München 1992.

HAJDÚ, Mária: A szabálysértési jogalkalmazás gondjai, in: Magyar Jog, 51, 2002, 4, 241.

KATHOLNIGG, Oskar: A kisebb súlyú bűncselekmények Németországban. A szabálysértésekről szóló törvény, in: Magyar Jog, 43, 1996, 8, 485-486.

KÁNTÁS, Péter: Egy alkotmánybírósági határozat margójára, in: Belügyi Szemle, 46, 1998, 6, 88-97.

KÁNTÁS, Péter: Mérlegen az új szabálysértési törvény, in: Belügyi Szemle, 47, 1999, 10, 18-26.

MADARÁSZ, Tibor: Az államigazgatási jogi szankció fogalma és fajtái, Budapest 1989.

MÁTHÉ, Gábor: Von der Übertretung bis zur Ordnungswidrigkeit - Entwicklung der Rechtsinstituts in Ungarn, in: A közigazgatási büntetőbíráskodás fejlődése az utolsó 100 évben, MÁTHÉ, Gábor - RÉVÉSZ, Tamás (eds.), Budapest 1986, 84.

MÁTHÉ, Gábor: Megoldhatatlan-e a szabálysértési felelősség, in: Belügyi Szemle, 1989, 2, 3-9.

MÁTHÉ, Gábor: Közigazgatási büntetőjog vagy "Janus-arcú" büntetőjog?, in: Magyar Közigazgatás, 51, 2001, 6, 323, 325.

MÁTHÉ, Gábor - PAPP, László: Javaslat A magyar szabálysértési jog továbbfejlesztésére, figyelemmel az Európai Emberi Jogi Egyezmény szövegére és az Emberi Jogok Európai Bíróságának joggyakorlatára, Ministry of the Interior: Budapest 1991, (Manuscript).

Memo of the lectures delivered at the meeting of the Club of Criminal Lawyers on 28 February 1992, Club of Criminal Lawyers: Budapest, 16 March 1992, (Manuscript).

MOLE, Nuala - HARBY, Catharina: The right to a fair trial. A guide to the implementation of Article 6 of the European Convention on Human Rights, Strasbourg 2001, 2006. 
MOLNÁR, Miklós: Adalékok a közigazgatási jogi szankció hazai elmélettörténetéhez, Budapest 1990.

NAGY, Marianna: A közigazgatási jogi szankciórendszer, Budapest 2000.

PAPP, László: A szabálysértési jog kialakulása és fejlődése, a hatályos szabálysértési jog jellemzői, a kodifikáció tendenciái hazánkban, Ministry of the Interior: Budapest 1992, (Manuscript).

Proposal, 6-92/1996, Ministry of the Interior - Ministry of Justice: Budapest 1996, (Manuscript).

Report: Report no. J/15234. of the Republic of Hungary, Budapest, 29 March 2005.

Report for case no. AJB-6727/2012, online: www.ajbh.hu/allam/jelentes/201206727.rtf (Downloaded 11 November 2013).

SPITZ, József - SZABÓ, Sándor: Jogalkalmazói pillanatfelvétel az új szabálysértési törvényröl, in: Magyar Jog, 48, 2001, 1, 7-23.

SZATMÁRI, László: Bírság a magyar államigazgatásban, Budapest 1990.

TAUBNER, Zoltán: Manuscript, Ministry of the Interior: Budapest, May 1991.

VITKAUSKAS, Dovydas - DIKOV, Grigoriy: Protecting the right to a fair trial under the European Convention on Human Rights, Strasbourg 2012.

ZÁMBÓ, Géza: Jogalkalmazói nézőpontú észrevételek a szabálysértésekről szóló 1999. évi LXIX. törvény módosítására vonatkozó tervezethez, in: Magyar Közigazgatás, 52, 2002, 4, 220-229.

\section{Author}

Zsuzsanna Árva Dr. PhD., habil.

Állam- és Jogtudományi Kar, Debreceni Egyetem

Faculty of Law, University of Debrecen

Kassai út 26, 4028 Debrecen, Hungary

arvazsuzsa@gmail.com 